\title{
Contextualizing the first-round failure of the AHCA: down but not out
}

\author{
Joshua A Hirsch, ${ }^{1}$ Andrew B Rosenkrantz, ${ }^{2}$ Greg N Nicola, ${ }^{3} \mathrm{H}$ Benjamin Harvey, ${ }^{4}$ \\ Richard Duszak Jr, ${ }^{5}$ Ezequiel Silva III, ${ }^{6}$ Robert M Barr, ${ }^{7}$ Richard P Klucznik, ${ }^{8}$ \\ Allan L Brook, ${ }^{9}$ Laxmaiah Manchikanti $^{10,11}$
}

'Neurolnterventional Radiology, Massachusetts General Hospital, Harvard Medical School, Boston, Massachusetts, USA

2Department of Radiology, NYU Langone Medical Center, New York, New York, USA

${ }^{3}$ Hackensack Radiology Group, Hackensack, New Jersey, USA

${ }^{4}$ Department of Radiology, Massachusetts General Hospital, Harvard Medical School, Boston, Massachusetts, USA

EEmory University School of Medicine, Atlanta, Georgia, USA ${ }^{6}$ South Texas Radiology Group, San Antonio, Texas, USA ${ }^{7}$ Mecklenburg Radiology Associates, Charlotte, North Carolina, USA

${ }^{8}$ Methodist Hospital, Houston, Texas, USA

Interventional Neuroradiology, Montefiore Medical Center, Albert Einstein College of Medicine, Bronx, New York, USA ${ }^{10}$ Pain Management Center of Paducah, Paducah, Kentucky, USA

${ }^{11}$ Department of Anesthesiology and Perioperative Medicine,

University of Louisville, Louisville, Kentucky, USA

\section{Correspondence to} Dr Joshua A Hirsch, Neurolnterventional Radiology, Massachusetts General Hospital, Harvard Medical School, Boston, MA 02114, USA;

Hirsch@snisonline.org

Received 17 April 2017 Accepted 18 April 2017 Published Online First 10 May 2017

CrossMark

To cite: Hirsch JA,

Rosenkrantz AB, Nicola GN et al. J Neurolntervent Surg 2017:9:595-600.

\section{ABSTRACT}

On 8 November 2016 the American electorate voted Donald Trump into the Presidency and a majority of Republicans into both houses of Congress. Since many Republicans ran for elected office on the promise to 'repeal and replace' Obamacare, this election result came with an expectation that campaign rhetoric would result in legislative action on healthcare. The American Health Care Act (AHCA) represented the Republican effort to repeal and replace the Affordable Care Act (ACA). Key elements of the AHCA included modifications of Medicaid expansion, repeal of the individual mandate, replacement of ACA subsidies with tax credits, and a broadening of the opportunity to use healthcare savings accounts. Details of the bill and the political issues which ultimately impeded its passage are discussed here.

\section{INTRODUCTION}

Healthcare reform had been attempted many times by the federal government with arguably the earliest proposal being the 1854 Bill for the Benefit of Indigent Insane, which was vetoed by then President Franklin Pierce. ${ }^{1}$ In 2010, President Barack Obama successfully pushed the Patient Protection and Affordable Care Act (ACA) through Congress. ${ }^{2}$ Votes on this legislation followed strict party lines, with no Republican support. ${ }^{3} 4$ The inability to draw any Republican support and the Democrats' use of the Budget Reconciliation Process to avert filibuster by the Republicans during ACA passage resulted in a multi-year rallying cry for the Republican Party and contributed to Democratic losses in subsequent elections.

The ACA created the Center for Medicare and Medicaid Innovation (CMMI). ${ }^{5}$ The CMMI was intended to facilitate value-based approaches to healthcare primarily by creating and piloting alternative payment models (APMs), for which $\$ 10$ billion in funding was earmarked. The Bundled Payments for Care Improvement Initiative ${ }^{67}$ and the maturation of Accountable Care Organizations $^{8-10}$ both derive from the CMMI and are of relevance to the neurointerventional community.

In a January 2015 commentary in the New England Journal of Medicine, former Health and Human Services (HHS) Secretary Sylvia Burwell presented the Obama administration's perspectives on where Medicare was headed. ${ }^{11}$ That treatise was notable for its ambitious timeline for the introduction of APMs (30\% of Medicare payments by 2016 and $50 \%$ by 2018). ${ }^{12}$ Burwell's delineation of a timeline helped shape the administration's goal of transforming the nation's healthcare delivery to a value-driven system and highlighted the seriousness of her agency's intent to move away from fee-for-service.

Partisan gridlock took a rare break in April 2015 with the passage of the Medicare Access and Children's Health and Insurance Program (CHIP) Reauthorization Act (MACRA). ${ }^{13}$ MACRA was approved with strong bicameral, bipartisan support. The legislation's initial headline news was as a permanent 'Doc Fix', repealing the Sustainable Growth Rate methodology for controlling Medicare costs that had plagued practitioners and patients since the passage of the Balanced Budget Act of $1997 . .^{14}$ It soon became clear, however, that MACRA included additional critical elements that would redefine payment policy for years to come by transitioning traditional fee-for-service volume-based medicine $e^{16} 1^{17}$ that neurointerventionalists are familiar with ${ }^{18} 19$ into a new valuebased paradigm. ${ }^{20-22}$

In November 2016, political pundits were surprised by the election of Donald J Trump to the presidency of the USA. As a candidate, Mr Trump had run on a platform to repeal and replace the ACA. Beyond that, he made substantial commitments regarding priorities for transforming US healthcare delivery, which will be detailed below.

\section{THE AFFORDABLE CARE ACT (ACA): 2017 STATUS}

The ACA itself was more than 2500 pages long, and over 70000 pages of related regulations have since been written ${ }^{23}$ and created two independent and powerful boards. ${ }^{24} 25$ The ACA had two fundamental but arguably disparate goals: (1) increasing the number of the insured; and (2) reducing the costs of healthcare. The ACA has clearly increased the number of people with insurance, with frequently quoted estimates in the range of 20 million additional people covered. ${ }^{26}$ This increase has been largely accomplished through two mechanisms: Medicaid expansion and, to a lesser extent, establishment of the health insurance marketplace (also referred to as health exchanges). ${ }^{27}$ The exchanges were designed to create a health insurance market for Americans earning more than 133\% over the poverty line (ie, those not qualifying for Medicaid). 
The ACA also drove greater levels of health insurance coverage via new employer and individual mandates, similar to those mandates previously enacted at the state level in Massachusetts during the tenure of Republican governor Mitt Romney (ie, 'RomneyCare').

Despite the good intentions of the bill, the complex regulatory framework of the ACA has been implicated in increasing out of pocket and deductible expenses for those on exchanges and employer-based health plans. ${ }^{23}$ For one, the ACA requires most health insurance plans to cover 10 categories of services known as 'essential health benefits' (box 1). ${ }^{2}$ These costly benefit packages have contributed to some of the affordability challenges for individuals with employer-based insurance. Defending his signature legislation in an article in the Journal of the American Medical Association, President Obama nonetheless claimed that the ACA provided significant cost containment, holding that costs would have been even higher if the ACA was not the law. ${ }^{28}$

Another key criticism of the ACA has been its treatment of the low-to-middle income working class. Recently, former President Bill Clinton—an unlikely critic of the ACA—stated:

So you have got this crazy system where, all of a sudden, 25 million more people have health care and then the people who are out there busting it, sometimes 60 hours a week, wind up with their premiums doubled and their coverage cut in half. It is the craziest thing in the world. ${ }^{29}$

What former President Clinton was describing was the following circumstance. Under the ACA, people with incomes below $133 \%$ of the federal poverty level could become eligible for free healthcare through Medicaid in states opting for Medicaid expansion, while those with incomes between 133\% and $400 \%$ of the federal poverty level would receive federal subsidies to purchase insurance in the ACA-created health exchanges. However, those not covered by their employers with incomes over $400 \%$ of the Federal Poverty Level (representing less than $\$ 100000$ dollars a year for a household of four) do not qualify for Medicaid or for federal subsidies to purchase insurance on the ACA-created health exchanges. They are often forced to purchase high-cost unsubsidized insurance on the exchanges or face the penalties of the individual mandate. Further, while employer-based insurance is non-taxable, these individually purchased policies are paid with post-tax dollars, thus accentuating this problem.

\section{Box 1 The 10 essential health benefits of the}

\section{Affordable Care Act}

- Ambulatory patient services

- Emergency services

- Hospitalization

- Maternity and newborn care

- Mental health and substance abuse disorder services, including behavioral health treatment

- Prescription drugs

- Rehabilitative and habilitative services and devices

- Laboratory services

- Preventive and wellness services and chronic disease management

- Pediatric services, including oral and vision care
THE REPUBLICAN LEGISLATION PRIOR TO THE AMERICAN HEALTH CARE ACT (AHCA)

In the 7 years since the passage of the ACA, there have been numerous Republican efforts to repeal it. These congressional efforts were largely for show since the proposals had essentially no chance of becoming law with President Obama in office. Some of these unsuccessful legislative efforts at ACA repeal warrant mention. Speaker of the House of Representatives Paul Ryan proposed his 'A Better Way' treatise. Representative Tom Price, an orthopedic surgeon now serving as the Secretary for HHS, proposed the 'Empowering Patients First Act'. Republican Senators Bill Cassidy and Susan Collins proposed the 'Patient Freedom Act of 2017'. Each of these efforts featured elements of particular importance to its author. For example, Ryan addressed Medicare Reform, Price addressed the physician shortage, and Cassidy and Collins addressed price transparency and affordability of emergency services.

\section{ENTER THE AMERICAN HEALTH CARE ACT (AHCA)}

Beginning in January 2017, the Republican Party enjoyed control of the Executive Branch and both houses of Congress. The party that had lamented the deficiencies of the ACA for over half a decade now held the power to 'fix' it. Action on the ACA was inevitable, if the Grand Old Party could agree on a replacement.

However, candidate Trump's promises were not necessarily fully aligned with typical Republican positions. ${ }^{30}$ In particular, Trump campaigned on providing insurance for everybody, described as universal coverage by his Democratic foes. He also indicated that there would be no cuts to the entitlements of Medicare, Medicaid and Social Security, contrary to many top Republicans' views. Several of Trump's other positions were more in line with his party. He spoke for the need to drive further improvements in the quality of care. He also supported allowing people to buy insurance across state lines, a concept that has enjoyed considerable support over time from various Republican leaders. ${ }^{30}$

By design, Medicaid is meant to cover the healthcare needs of low-income and disabled Americans. Medicaid funding involves a complex interplay between the federal government and the states whereby spending is shared between the federal government and individual states, with each paying a set percentage of each beneficiary's costs. States must meet certain requirements for coverage set by the federal government in order to qualify for matching funds. In states where people earn less, the federal government pays a higher percentage of beneficiary costs, and Medicaid is subsidized based on the number of people in the program.

Further complicating replacement has been the issue of 'Medicaid expansion'. This element of the ACA was problematic for many Republicans. First, the Republican Party in general had concerns that this expansion constituted an unfunded entitlement. Second, there was concern that, after the federal government stopped providing the initial level of support for the expansion, individual states would have far greater financial liability than prior to the ACA. Third, there was philosophical opposition to the use of Medicaid in this way. Nonetheless, faced with the reality of federal dollars being available and potentially many newly insurable beneficiaries, 31 states and Washington DC (including 12 states with Republican governors and large Republican constituencies) accepted the federal dollars associated with that expansion. These Republican governors 
have all since expressed concern with efforts to roll back Medicaid expansion as part of ACA repeal efforts. ${ }^{31}$

\section{RECONCILIATION}

The Senate's passage of legislation often requires a 60-vote super-majority. This is because the minority party can engage in a filibuster immune to cloture (a procedure for ending a debate and taking a vote), thus preventing and hence forestalling efforts at partisan legislation, and thereby prevent passage of bills with only a simple majority. After the November 2016 elections, the Republicans enjoy 52 seats in the US Senate. Thus, the Senate Republicans do not themselves have sufficient votes to invoke cloture of a filibuster by the minority Democratic Party. Realistically, for Senate Republicans to achieve a filibusterproof super-majority, they would have to work together with Democratic Senators in states that voted heavily for Trump, an unlikely scenario.

Reconciliation, however, is a process that allows the Senate to pass legislation with only a simple majority. ${ }^{32}$ What is reconciliation? The Congressional Budget Act of 1974 sought to rationalize the process by which Congress set the federal budget. This law created House and Senate Budget Committees and established the Congressional Budget Office (CBO) as an impartial source of cost estimates and budget projections. The 1974 Congressional Budget Act created a process for 'reconciling' the tax code and laws authorizing mandatory programs to the latest budget resolution. This process, as such, was designed primarily for addressing budgetary issues. Understanding reconciliation is critical to informing elements of the way the American Health Care Act (AHCA) and previous healthcare legislation are crafted, reflecting the political realities of what might and might not be accomplished through this majority process (rather than traditional legislation that would require 60 Senate votes). ${ }^{32}$

Since 1980, budget reconciliation has been used as a mechanism to pass major pieces of legislation such as the Consolidated Omnibus Budget Reconciliation Act of 1985, which lets ex-employees stay on their previous employer's health plan, and the Balanced Budget Act of 1997 which imposed the Sustainable Growth Rate on Part B Payment from Medicare. A more recent example is the Health Care and Education Reconciliation Act of 2010, which Democrats used to amend the ACA after the House passed the previously approved Senate version to avoid a filibuster by the Republicans. This bill included only budgetary items; it nationalized the student loan industry and amended the ACA by increasing levels of subsidies. $^{33}$

Using the reconciliation process, cloture can be invoked with a simple majority vote subsequently restricting the length of a debate and disabling the filibuster. In the Senate, debate on budget reconciliation bills is limited to 20 hours, and nongermane amendments are not permitted. Despite these easements, reconciliation is not a panacea for Washington gridlock. Congress must first pass a budget resolution with reconciliation instructions. When multiple committees are involved in the budget resolution, the Budget Committee combines them and sends the resulting bill to the floor of the House. The Senate may only use reconciliation for a single spending bill, a single revenue bill, and a single bill affecting the debt limit, per year. ${ }^{33}$ While these three areas may be incorporated in a single bill or multiple bills, the cap on one such reconciliation act per year remains. Since 2011, Republicans have adopted rules that block the use of reconciliation to expand mandatory spending, even if such spending is offset (or more than offset) by other cuts or taxes. In 1985, Senate Minority Leader Robert Byrd effectively limited the extent of what could be accomplished with this budget reconciliation process, establishing the so-called 'Byrd rule'. In the case of potential ACA repeal, the most important implication of the Byrd Rule is that it cannot be used to pass provisions on major legislation that are not directly related to spending or revenue. ${ }^{33}$

On 12 January 2017 in the Senate and then on 13 January in the House, Republicans took votes allowing the use of the budget reconciliation process to remove large elements of the ACA. ${ }^{34}$ At that time, Republicans seemed well positioned to move forward with critically revising Obamacare.

\section{DETAILS OF AHCA AND COMPARISON WITH ACA}

In early March 2017, a draft of the AHCA was released in the House and almost instantly attacked from multiple sources, including but not limited to conservative Republicans, Democrats, patient advocacy groups (such as the American Association of Retired Persons), the American Medical Association, and the American Hospital Association. The reasons for attacking were broad and varied, ranging from conservatives who dubbed it 'Obamacare Lite' to many moderates and liberals who stated it will jeopardize insurance coverage for millions of Americans.

\section{Medicaid expansion}

Medicaid expansion was a key aspect of the ACA targeted by the AHCA. In their initial rollout of the AHCA, Republicans capped Medicaid support after 2020. To determine the amount of funding states would receive in subsequent years, the AHCA estimates the costs per enrollee category in 2016. In 2019, the per-enrollee costs were to be adjusted by a medical inflation index to create a baseline cost for each of these enrollee types. Then in 2020, the baseline amounts would be multiplied by the number of Medicaid participants in each state plus further medical inflation, allowing the federal government to cap its share of expenses. Once that cap is reached, the state would then be responsible for all additional expenses. ${ }^{35}$

Under the AHCA, states including the District of Columbia that had accepted Medicaid expansion would continue to receive federal funds for beneficiaries that joined Medicaid pursuant to the ACA. However, such states would not be permitted to accept new expansion enrollees starting in 2020. For the 19 states that did not accept expanded Medicaid under the ACA, the AHCA would have provided additional safety net funding that would allow these states to increase payments to Medicaid providers from 2018 to 2022 . The AHCA provided \$10 billion dollars to even the playing field in this fashion between states with and without Medicaid expansion so as to not penalize states that had decided against accepting the federal Medicaid expansion. Depending on which of these two categories a state belongs, planned cuts under the ACA to hospitals that treat a disproportionate number of indigent patients ('disproportionate share hospitals') would be reversed in either 2020 or 2018, respectively. ${ }^{35}$

\section{Individual mandate}

As far back as 1989, Stuart Butler, the Heritage Foundation's Director of Domestic Policy Strategies, championed the notion that every resident of the USA must, by law, be enrolled in an adequate healthcare plan to cover major healthcare costs. In 2003 Mr Butler testified before the Senate Special Committee, reviewing concepts of both 'hard' and 'soft' mandates. ${ }^{36} 37$ Interestingly, in the 2008 presidential election, Barack Obama came out firmly against an individual health insurance mandate, 
a concept eventually included within the ACA. As President Obama embraced the individual mandate, many conservatives became less enthusiastic about such an imperative.

The AHCA, if passed, would have repealed the individual mandate. But, in keeping with Candidate Trump's promises, the AHCA would not have repealed current protections for people with pre-existing conditions. These circumstances enable people to simply wait until the last moment to get healthcare insurance. To avoid that possibility, the AHCA would have instituted a 'continuous coverage' requirement, permitting insurers to impose a penalty on individuals who allow their healthcare coverage to lapse. How would continuous coverage take shape? Individuals can freely enroll in insurance plans for 60 days after a qualifying life event such as the loss of existing insurance coverage or a major change in residence or employment. If coverage is continuously maintained, the individual can enroll or re-enroll in a new plan at the standard price for the next year. If, however, there is a gap in coverage for a minimum of 63 continuous days, insurers would then be required to charge a $30 \%$ penalty on premiums for one full year. ${ }^{38}$

\section{Subsidies/credits}

The ACA provided various insurance subsidies based largely on income and costs. The AHCA would have replaced those subsidies with age-based credits. Specifically, regardless of premiums, the bill would have provided purchasers of insurance a refundable tax credit that increases with age. In distinction to the ACA, credits could be used for insurance plans not involved with exchanges. Older Americans could be charged more under the AHCA than under the ACA (5 times, rather than 3 times, the rates for younger individuals). This greater disparity would be partially addressed by the age adjustment on credit amounts. The AHCA credits would be reduced, and ultimately eliminated, based on progressively higher income. ${ }^{38}$

\section{Health savings accounts}

The AHCA would have encouraged the use of healthcare saving accounts (HSAs), consistent with a long-standing Republican position. HSAs are tax advantaged savings accounts that can be used for out of pocket healthcare expenses. The AHCA would also have expanded existing iterations of HSAs-for example, by allowing individuals to deposit leftover funds from their agebased tax credit.

\section{Other provisions}

The AHCA also proposed to cover much additional ground beyond what might be reasonably covered in detail in this narrative review. The bullet points below highlight some of those elements.

- The AHCA would have repealed the ACA's requirement that insurers classify their plans as gold, silver, or bronze depending on the share of health costs covered by the plan.

- The AHCA would have appropriated \$15 billion annually for a 'Patient and State Stability Fund'. While intended to stabilize state insurance markets, the fund would provide states much greater flexibility in establishing state-wide healthcare policy. Examples of how these states may apply the funds include:

- Providing financial assistance to high-risk individuals

- Stabilizing premiums in the individual insurance market

- Reducing coverage costs for high-risk individuals

- Promoting greater insurer participation in the individual market

- Promoting access to preventative services
- Providing payments to providers for certain services

- Reducing out of pocket costs for insurance enrollees.

- The AHCA would have repealed multiple taxes imposed by the ACA such as the medical device excise tax.

- The AHCA would also have increased funding for the Community Health Center Program.

The AHCA would not have impacted these elements of the ACA:

- Ban on insurers being able to not cover people with preexisting health conditions.

- Children staying on their parents' health insurance policies until age 26.

- Barring insurers from imposing annual or lifetime limits on coverage.

- Barring insurers from charging women more for the same services as men.

\section{THE CONGRESSIONAL BUDGET OFFICE (CBO) WEIGHS IN}

The $\mathrm{CBO}$ is designed to be a non-partisan office of the federal legislative branch that produces 'independent analyses of budgetary and economic issues to support the Congressional budget process'. ${ }^{39}$

On 17 March 2017 the CBO released its report indicating that the AHCA would reduce federal deficits by $\$ 337$ billion over the coming decade. Additionally, it would substantially increase the number of uninsured relative to the current law. Savings would accrue largely from reductions in outlays for Medicaid and from the elimination of subsidies. Savings would be limited by the simultaneous reduction of $\$ 900$ billion in revenue largely from changes in the tax code. In terms of health insurance coverage, about 14 million more people would become uninsured as early as 2018. This abrupt increase would largely stem from repealing the individual mandate, such that people would no longer be required to buy insurance. Over time, as federal subsidies diminish, the CBO projected that there would be 21 million more uninsured in 2020, rising to 24 million in $2026 .^{40}$

Remembering that much of the greater number of those presently insured occurred with increases in the number of patients covered by Medicaid, it is perhaps not surprising that the reductions in the number of people covered by insurance between 2018 and 2026 would also relate to changes in Medicaid enrollment. In 2026, an estimated 52 million people would be uninsured, compared with 28 million who are projected to lack insurance that year under current law. ${ }^{40}$ As the AHCA became modified during the House debate following the initial draft release, the savings that were to be achieved diminished to $\$ 186$ billion. $^{4142}$

\section{UNDERSTANDING THE FREEDOM CAUCUS POSITION}

The House Freedom Caucus was formed in 2015. This group aligns itself with the Tea Party. One of its early principles was a willingness to vote against then Speaker of the House John Boehner on legislation that the group opposed. ${ }^{43}$ That foretold how the Caucus might interact with Republican leadership when they felt it was not standing up for values that its members considered critical. In its mission statement, the Freedom Caucus prioritizes "support (for) open, accountable and limited government, the Constitution and the rule of law, and policies that promote the liberty, safety and prosperity of all Americans". ${ }^{4}$

House Freedom Caucus Chair Mark Meadows (R-N.C.) indicated on multiple occasions that he was working to get the approximately three dozen Freedom Caucus members to vote 
'yes' on the AHCA. It is important to remember that members of this Caucus were likely some of the same people who previously threatened to 'close the government' through opposition to required funding of government operations over anger with the ACA. The Caucus also strongly opposed the AHCA, with demands ranging from wanting less insurance requirements to repealing essential benefits, or even Title 1 of the ACA. Title 1 is entitled "QUALITY, AFFORDABLE HEALTH CARE FOR ALL AMERICANS" " (sic); the essence of the ACA legislation.

The House of Representatives was scheduled to vote on the AHCA on Thursday 23 March 2017, 7 years to the day after the ACA was signed into law. A decision was made to delay the vote for 1 day while the Trump administration, Speaker Paul Ryan, and other House leaders searched for changes to the bill that could bring in sufficient support from disparate factions, most notably the Freedom Caucus. One suggested idea for a new version of the bill included repeal of the requirement for the 10 essential benefits, especially relevant to the radiology profession given the threat this could pose to screening services.

Multiple challenges emanated from these discussions. First, even with this transition to a Republican controlled Federal government, it was not clear that the Freedom Caucus could be counted on for their support. Second, pulling the 10 essential benefits strongly risked lowering support from moderate Republicans, already under significant pressure from constituents because of negative publicity related to the $\mathrm{CBO}$ estimate of significant increases in the uninsured population under the AHCA. Third, repeal of the essential benefits also risked the Bill no longer meeting the requirement to only address budgetary issues in order to constitute reconciliation legislation in the Senate (and thus be immune to a Democratic filibuster). Ultimately, the Bill was withdrawn on 24 March 2017 when it became clear that there was insufficient House Republican support for passage.

\section{DISCUSSION}

The ACA was consequential legislation that sought to both make healthcare more affordable and enhance coverage. It was passed in 2010 without Republican support in either the House or the Senate. The next 7 years were filled with Republican-led rallies and legislative efforts that were united in their concept of repealing the ACA. Indeed, for three election cycles, Republican candidates centered much of the focus of their successful campaigns on discontent with the ACA.

Given the rhetoric of the 2016 campaign and the eventual election of Donald Trump ${ }^{45}$ Republicans seemed poised to capitalize on this long-standing position. Moreover, the early steps of both houses of Congress followed by the appointment of Representative Tom Price (a vocal critic of the ACA) as HHS Secretary cemented the clarity of this approach. The Trump administration started the term with an apparent sharp focus, including the signing of the Executive Order Minimizing the Economic Burden of the Patient Protection and ACA Pending Repeal. ${ }^{46}$

Over the next few months, however, compromise with Democrats proved difficult on this issue. First, many Congressional Democrats were reluctant to repeal and replace the signature legislation of the most recent Democratic president. Second, while acknowledging challenges with the ACA, it was their general belief that it made greater sense to modify and improve the existing law rather than 'repeal and replace'.

Understanding that reality, legislative language needed to be developed that could bypass the likelihood of a Democratic filibuster in the Senate. Republicans thus needed to craft a bill that could be passed using the reconciliation process, where a simple 50 vote majority would allow it to pass, given the role of Vice President Michael Pence to cast tie-breaking votes. The Byrd rule meant that any proposed ACA repeal legislation would largely be limited to budgetary issues. Moreover, the legislation was complicated by campaign promises around healthcare made by then candidate Trump. Significant frustration appeared relatively early, with conservatives in both the House and Senate expressing frank irritation with their inability to participate in the crafting of the legislation. Once the legislation was revealed, criticism was levied that the AHCA was 'Obamacare Lite' and, as a result, the Freedom Caucus amongst others could not support its passage. Attempts to assuage the Freedom Caucus, in turn, had a negative impact on support from the more moderate members of the Republican establishment. Given the angst among Republicans, red state Democrats were in a somewhat unexpected luxurious position of not needing to make difficult choices, as it was clear this effort was not based on outreach across the aisle and the Republicans were not united themselves.

The House vote originally planned for Thursday March 23rd was postponed for 1 day and then, the next day, ultimately canceled. While in the ensuing days the Trump administration cast blame on many individuals, in reality, Congressional Republicans could not agree on a bill. Had the Republicans been able to limit the number of defections, a House bill could have been passed along strictly partisan lines. The Senate has not yet put forward legislation of its own.

Since the initial failed attempt at AHCA passage, moderate House Republicans have resurrected efforts to achieve ACA repeal, proposing a range of modifications to the earlier bill to garner greater House Freedom Caucus support. For example, as this manuscript goes to press, it has been proposed that states be allowed to apply for a waiver to the ACA's essential health benefits coverage requirement. Nonetheless, House Freedom Caucus opposition continues to appear strong. On the chance that a revised bill does gain enough Conservative Republican support to pass the House, it seems unlikely that such a bill would also receive enough Democratic support to achieve the required super-majority in the Senate. Moreover, members of Congress facing re-election in the next election cycle may weigh the increasing levels of public support for the ACA in considering their potential sponsorship of any revised bill. Nonetheless, while the prospects for successful ACA repeal legislation are bleak, the Executive Branch seems fully prepared to undermine the ACA through executive orders and HHS rule-making. Such efforts would leverage Executive Branch discretion and include, for example, ceasing advertising that would encourage healthier patients to enroll in the exchanges and otherwise reducing ACA funding to the extent possible. Such Executive Branch action could introduce sufficient instability into the ACA's health insurance marketplace to prompt some insurers to exit the exchanges and potentially leave certain regions of the USA without any participating insurers. Weakening of the ACA in this fashion would inevitably influence how both Republicans and Democrats approach ACA repeal and other health insurance reform efforts in future years.

\section{CONCLUSION}

Since the 2010 passage of the ACA there have been numerous Republican legislative efforts to modify, repeal, and replace Obamacare. In retrospect, those efforts were 'protected' by never having a chance to be signed by the President and thus made into law. The Republicans' current control of both houses of Congress and the Executive Branch has since created a clear 
opportunity to move forward with a specific policy agenda to 'repeal and replace'. On 24 March 2017, when the vote on the AHCA was canceled, Speaker of the House Paul Ryan stated, "Doing big things is hard. All of us, all of us-myself included -we will need time to reflect on this moment and what we could have done to do it better". Later in that same news conference he indicated that ... "Obamacare is the law of the land. It will remain the law of the land until it is replaced". ${ }^{47}$ Indeed, without bipartisan support, the prognosis for substantive and lasting ACA reform is guarded.

Contributors JAH developed the original draft. All authors were given an opportunity to review and make substantial editorial suggestions, many of which were included in the final version.

Competing interests $A B R$ and $R D$ are supported by research grants from the Harvey L Neiman Health Policy Institute.

Provenance and peer review Commissioned; internally peer reviewed.

\section{REFERENCES}

1 Pierce F. Veto message. Livonia, MI: LONANG (Laws Of Nature And Nature's God) Institute, 1854. http://lonang.com/library/reference/1854-pvm/ (accessed 2 Apr 2017)

2 Public Law No: 111-148: H.R. 3590. Patient Protection and Affordable Care Act. 23 March 2010.

3 Manchikanti L, Hirsch JA. Patient Protection and Affordable Care Act of 2010: a primer for neurointerventionalists. J Neurointerv Surg 2012;4:141-6.

4 Manchikanti L, Hirsch JA. Obama health care for all Americans: practical implications. Pain Physician 2009;12:289-304.

5 Centers for Medicare and Medicaid Services (CMS). https://innovation.cms.gov (accessed 14 Mar 2017)

6 Centers for Medicare and Medicaid Services (CMS). https://innovation.cms.gov/ initiatives/bundled-payments/ (accessed 14 Mar 2017).

7 Hirsch JA, Leslie-Mazwi TM, Barr RM, et al. The bundled payments for care improvement initiative. J Neurointerv Surg 2016;8:547-8.

8 Centers for Medicare and Medicaid Services (CMS). https://www.cms.gov/Medicare/ Medicare-Fee-for-Service-Payment/ACO/index.html?redirect=/aco (accessed 14 Mar 2017).

9 Meehan TM, Harvey HB, Duszak R Jr, et al. Accountable care organizations: what they mean for the country and for neurointerventionalists. J Neurointerv Surg 2016:8:654-7.

10 Hirsch JA, Leslie-Mazwi TM, Meyers PM, et al. Accountable care. J Neurointerv Surg 2015. doi: 10.1136/neurintsurg-2015-011899. [Epub ahead of print 17 Jun 2015]

11 Burwell SM. Setting value-based payment goals-HHS efforts to improve U.S. health care. N Engl J Med 2015;372:897-9.

12 Hirsch JA, Leslie-Mazwi TM, Barr RM, et al. The Burwell roadmap. I Neurointerv Surg 2016;8:544-6.

13 The Medicare Access and CHIP Reauthorization Act of 2015. http://www.congress. gov/bill/114th-congress/house-bill/2 (accessed 2 Jun 2015).

14 Hirsch JA, Rosman DA, Liu RW, et al. Sustainable growth rate 2013: time for definitive intervention. J Neurointerv Surg 2013;5:382-6.

15 Hirsch JA, Manchikanti L. The sustainable growth rate: a 2014 update. J Neurointerv Surg 2014:6:411-12.

16 Hirsch JA, Leslie-Mazwi TM, Nicola GN, et al. Current procedural terminology; a primer. J Neurointerv Surg 2015;7:309-12.

17 Hirsch JA, Silva E III, Nicola GN, et al. The RUC: a primer for neurointerventionalists. I Neurointerv Surg 2014:6:61-4.

18 Donovan WD, Leslie-Mazwi TM, Silva E III, et al. Diagnostic carotid and cerebral angiography: a historical summary of the evolving changes in coding and reimbursement in a complex procedure family. J Neurointerv Surg 2014;6:712-17.
19 Hirsch JA, Donovan WD, Leslie-Mazwi TM, et al. Component coding and the neurointerventionalist: a tale with an end. J Neurointerv Surg 2013; 5:615-19.

20 Hirsch JA, Leslie-Mazwi TM, Patel AB, et al. MACRA: background, opportunities and challenges for the neurointerventional specialist. J Neurointerv Surg 2016;8:868-74.

21 Hirsch JA, Harvey HB, Barr RM, et al. Sustainable growth rate repealed, MACRA revealed: historical context and analysis of recent changes in Medicare physician payment methodologies. AJNR Am J Neuroradiol 2016;37:210-14.

22 Hirsch JA, Rosenkrantz AB, Liu RW, et al. The episode, the PTAC, cost, and the neurointerventionalist. J Neurointerv Surg 2016. doi: 10.1136/neurintsurg-2016012885. [Epub ahead of print 1 Dec 2016]

23 Manchikanti L, Helm li S, Benyamin RM, et al. A critical analysis of Obamacare: affordable care or insurance for many and coverage for few? Pain Physician 2017;20:111-38

24 Manchikanti L, Hirsch JA. The Independent Payment Advisory Board: impact on neurointerventionalists. J Neurointerv Surg 2012:4:468-72.

25 Hirsch JA, Barr RM, McGinty G, et al. Affordable care 2014: a tale of two boards. J Neurointerv Surg 2014;6:718-20.

26 Butler SM. The future of the Affordable Care Act: reassessment and revision. JAMA 2016:316:495-7.

27 Manchikanti L, Hirsch JA. Repeal and replace of affordable care: a complex, but not an impossible task. Pain Physician 2016;19:E1109-13.

28 Obama B. United States health care reform: progress to date and next steps. JAMA 2016;316:525-32.

29 Frieden J. Affordable Care Act pounded by hurricane, Bill Clinton. MedPage Today, 5 October 2016

30 http://www.politico.com/story/2017/03/trump-obamacare-promises-236021 (accessed 26 Mar 2017)

31 http://www.vox.com/policy-and-politics/2017/2/25/14738710/ gop-republican-medicaid-plans (accessed 26 Mar 2017).

32 http://www.vox.com/policy-and-politics/2016/11/23/13709518/ budget-reconciliation-explained (accessed 26 Mar 2017).

33 https://en.wikipedia.org/wiki/Reconciliation_(United_States_Congress) (accessed 2 Apr 2017)

34 https://www.nytimes.com/2017/01/13/us/politics/ affordable-care-act-congress-budget.html?_r=0 (accessed 27 Mar 2017).

35 https://www.congress.gov/115/bills/hr1628/BILLS-115hr1628rh.pdf (accessed 19 March, 2017).

36 http://www.huffingtonpost.com/chris-weigant/the-individual-mandates-c_b_ 1386716.html (accessed 2 Apr 2017)

37 http://healthcarereform.procon.org/view.resource.php?resourcelD=004182 (accessed 2 Apr 2017).

38 http://www.politico.com/pro/amer-health-care-act-datapoint (accessed 27 Mar 2017)

39 Introduction to CBO.PDF Congressional Budget Office (accessed 15 Mar 2017). https://www.cbo.gov/sites/default/files/cbofiles/attachments/2016-IntroToCBO.pdf

40 https://www.cbo.gov/publication/52486 (accessed 1 Apr 2017).

$41 \mathrm{http}: / / \mathrm{crfb}$. org/blogs/what-cbo-says-about-updated-ahca (accessed 2 Apr 2017).

42 https://www.cbo.gov/system/files/115th-congress-2017-2018/costestimate/hr1628. pdf (accessed 3 Apr 2017).

43 Lizza R. A House Divided. The New Yorker (accessed 9 Dec 2015). http://www. newyorker.com/magazine/2015/12/14/a-house-divided

44 http://time.com/4718360/freedom-caucus-donald-trump-what-to-know/ (accessed 27 Apr 2017).

45 Rosenkrantz AB, Nicola GN, Hirsch JA. Anticipated impact of the 2016 federal election on federal health care legislation. J Am Coll Radiol 2017:14:490-3.

46 https://www.whitehouse.gov/the-press-office/2017/01/2/ executive-order-minimizing-economic-burden-patient-protection-and (accessed $2 \mathrm{Apr}$ 2017)

47 http://time.com/4713114/paul-ryan-ahca-health-care-failure-transcript/ (accessed 2 Apr 2017) 